\title{
Assessing learner satisfaction by simultaneously measuring learner attitude, motivation, loyalty, and service quality in English academies
}

\author{
Jennifer Vu Huong $^{\mathrm{a}^{*}}$, Marti Casadesus ${ }^{\mathrm{b}}$, Frederic Marimon ${ }^{\mathrm{c}}$ \\ ${ }^{a}$ Department of Business Management and Product Development, University of Gerona, \\ Gerona, Spain; ${ }^{b}$ Department of Business Management and Product Development, \\ University of Gerona, Gerona, Spain; 'Department of Economy and Business \\ Organization, Universitat Internacional de Cetalunya, Barcelona, Spain
}

The aims of this study are threefold in their approach to English academy teaching: (i) to assess learner satisfaction, (ii) to assess the impact of satisfaction on loyalty and (iii) to assess the three constructs that we considered to be the antecedents of learner satisfaction: learner motivation, learner attitude, and service quality. To collect the data, a questionnaire was developed and delivered to 334 English learners in Spain in 2014. We concluded from these results that learner satisfaction is directly influenced by service quality; whereas learner motivation and learner attitude have no significant impact on learner satisfaction. Moreover, learner satisfaction has a strong impact on learner loyalty. The results also indicated that intrinsic motivation has a direct positive correlation with learner attitude and service quality, whilst extrinsic motivation has an insignificant relationship with learner attitude and a negative relationship with service quality. Among the four dimensions used to measure service quality two factors namely teachers and tangibles (materials, equipment, and facilities) - are the most important.

Keywords: satisfaction, motivation, attitude, loyalty, service quality, English learning

*Corresponding author. Email: huongvuvu.hut@gmail.com 


\section{Introduction}

Increasing the level of learner satisfaction is always the main concern for many education organizations. This is why it is important to determine what the most important factors are in terms of influencing learner satisfaction. By doing so, the organizations will be able to work on improving these specific factors in order to enrich overall learner satisfaction.

Due to the fact that the demand for English learning has dramatically increased in recent years, the assessment of learner satisfaction and the quality of English teaching therefore has become a strategic issue all over the world, and in particular for specialized academies.

Although there have been several studies conducted on assessing learner satisfaction (Elliott, 2002; Mai, 2005; Stodnick and Rogers, 2008), little research has been carried out to simultaneously assess it with other important factors like learner motivation, learner attitude, learner loyalty, and service quality in general, and in the English teaching field in particular.

To fill the gap in the literature review, this study proposes an innovative method to assess learner satisfaction by simultaneously measuring three antecedent factors motivation, attitude, and teaching quality (assessed by a modified SERVQUAL scale) and the resulting factor - loyalty in an English teaching context.

$\underline{\text { To summarize: }}$ the aims of this study are threefold: (i) to assess learner satisfaction in the context of English teaching, (ii) to assess the impact of satisfaction on loyalty, and (iii) to assess the three constructs that are considered as antecedents of learner satisfaction: learner motivation, learner attitude, and service quality. The paper is organized as follows; first a literature review is performed and hypotheses are presented. The methodology and data analysis are explained. A section is then 
devoted to the results of the study and discussion of these results. Finally, the conclusions are presented, along with a discussion of the limitations of the study and suggestions for future research ideas.

\section{Literature review and hypothesis development}

\section{Learner motivation}

Gardner (1985) refers to the term motivation as being how much each individual works or strives to learn a language because of a desire to do so, and the satisfaction experienced in this activity.

In the early studies of Gardner and Lambert (1972), motivation is categorized into two types: integrative motivation and instrumental motivation. Other researchers such as Deci and Ryan (1980), divided motivation into 2 groups: intrinsic motivation and extrinsic motivation.

In this study, learner motivation was assessed via two types: intrinsic motivation and extrinsic motivation.

\section{Learner attitude}

According to Nasser and Majid (2011), attitudes are important and they can be changed. Good attitudes are needed to raise the efficiency of learners in language classes. The researchers also indicated that an attitude can be considered as a set of beliefs while motivation is a reason for doing something. Attitude and motivation are therefore linked: attitude can drive motivation, and motivation can change attitude. In this study, learner attitude and learner motivation were considered as two separate factors and the correlation between them was investigated.

\section{Service quality}


Several empirical studies have reported that service quality is commonly linked to levels of customer satisfaction (Spreng and Mackoy, 1996). SERVQUAL (Parasuraman et al., 1995) is a commonly used method to measure the service quality in general, and it has already been identified as having the potential to measure service quality in a postsecondary institution (Leo, 2008).

In an educational context, there is much more research that measures quality by indicators such as teachers, course, facilities, support services, etc (refer to Table 1 below).

Table 1.Studies assessing service quality

\begin{tabular}{|c|c|c|}
\hline No & $\begin{array}{l}\text { Study } \\
\text { (authors and publishing year) }\end{array}$ & Indicators used to assess Service quality \\
\hline 1 & Navarro et. al. 2005 & $\begin{array}{ll}\text { Perceived performance dimensions: } \\
\text { - } & \text { Teaching methods } \\
\text { - } & \text { Administration } \\
- & \text { Teaching staff } \\
- & \text { Enrolment process } \\
- & \text { Infrastructures } \\
\end{array}$ \\
\hline 2 & Helgesen and Nesset, 2007 & $\begin{array}{ll}\text { Service quality: } \\
- & \text { Informational aspects } \\
- & \text { Social aspects } \\
- & \text { Facilities } \\
\end{array}$ \\
\hline 3 & Stodnick and Rogers, 2008 & $\begin{array}{ll}\text { SERVQUAL } \\
- & \text { Assurance } \\
- & \text { Empathy } \\
- & \text { Responsiveness } \\
- & \text { Tangibles } \\
- & \text { Reliability } \\
\end{array}$ \\
\hline 4 & Babar and Kashif, 2010 & $\begin{array}{ll}- & \text { Teachers' expertise } \\
\text { - } & \text { Courses offered } \\
\text { - } & \text { Learning Environment } \\
\text { - } & \text { Classroom facilities } \\
\end{array}$ \\
\hline 5 & Toni Lupo, 2013 & 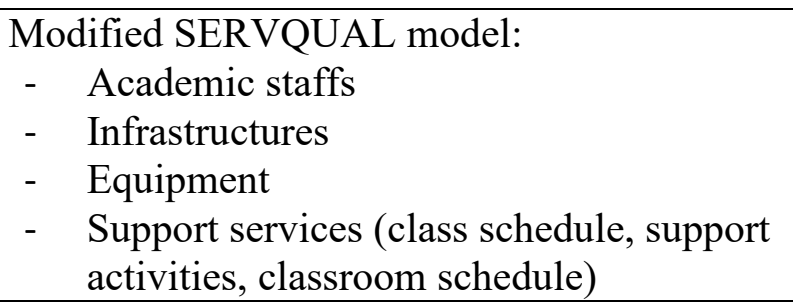 \\
\hline
\end{tabular}




\section{Learner satisfaction}

Customer satisfaction is seen as a key performance indicator within business (Gitman et al., 2005). Therefore, in the education context, many universities have incorporated some measure of satisfaction in their marketing campaigns, recruitment initiatives, and planning processes (Elliott, 2002). Learner satisfaction has been assessed directly via overall satisfaction (Mai, 2005) or satisfaction with separate indicators such as satisfaction with courses, and satisfaction with instructors (Stodnick and Rogers, 2008).

\section{Learner loyalty}

According to Leyla and Ali (2012), loyalty can be defined as the tendency of a learner to choose the same provider or service over another for a particular need. In their study, loyalty was measured by the intention to select the same university, recommendation to others, and intention to leave the university when possible. Patterson et al. (1997) demonstrated a very strong empirical link between customer satisfaction and repurchase intentions.

\section{Hypothesis development}

\section{H1: Learner motivation influences learner satisfaction}

The relationship between learner satisfaction and learner motivation has been investigated by recent research in the field of higher education and online-learning. Lim (2004) indicated that learner motivation and learner satisfaction in online-learning have a positively interrelated relationship. In a later study, Hsiu-Fenget al. (2013) also stated that learner motivation is a strong predictor of learner satisfaction in online learning. In this study, a hypothesis (H1) is proposed in an English teaching context: learner motivation influences learner satisfaction. 


\section{H2: Learner attitude influences learner satisfaction}

Some studies have shown that learner attitude is linked to learner satisfaction. Arbaugh (2000) indicated that learner satisfaction includes individuals' attitudes towards the education process. In an English learning context, learners who have a bad attitude toward learning may have poor results to their studying (Gan et al., 2004).

The researcher in this study proposed a hypothesis (H2) to clarify the relationship between learner attitude and learner satisfaction in an English learning context: learner attitude influences learner satisfaction when learning English.

\section{H3: Service quality influences learner satisfaction}

Several empirical studies have reported that service quality is an antecedent of customer satisfaction (Spreng and Mackoy, 1996).

To assess learner satisfaction in the context of English teaching, the relationship between learner satisfaction and the quality of English teaching was investigated in this study with a hypothesis (H3): service quality influences English learner satisfaction.

\section{H4: Learner satisfaction influences learner loyalty}

Several studies have indicated that customer loyalty/learner loyalty has a positive relationship with customer satisfaction/learner satisfaction. Zhaohua et al. (2010) indicated that customer loyalty is positively impacted by customer satisfaction. According to Leyla and Ali (2012), one of the aspects to evaluate learner satisfaction is the loyalty degree of learners.

In this study, the researcher hypothesized that it is also true in the case of English learning that (H4): learner satisfaction influences learner loyalty.

\section{H5: Learner motivation correlates with learner attitude}

Some previous studies have been conducted to investigate the relationship between 
learner motivation and learner attitude in the field of education. If the attitude of the learner increases, integrative or instrumental motivation will also increase, and vice versa (Nada, 2010). The studies of Nasser and Majid (2011) found that there is a direct link between the efficiency of learners in language classes, and motivation and attitude. Youssef (2012) indicated that the positive attitude of a person can increase the existing motivation in language learning.

To clarify the relationship between learner motivation and learn attitude in the English teaching field, a hypothesis (H5) in this study was proposed: learner motivation correlates with English learner attitude.

\section{H6: Service quality correlates with learner motivation}

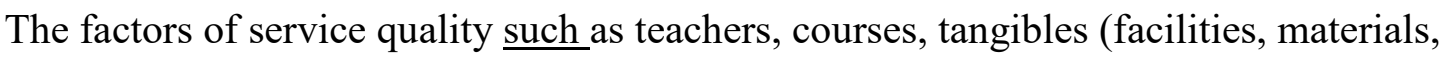
and environment) and support services (registration process, administration support) have been found to have a strong relationship with learner satisfaction. For example, Agita (2010) stated that intrinsic motivation for study choice and satisfaction with teachers are correlated. Moreover, Nada (2010) argued that learner motivation toward learning English is positively affected by teachers and class courses. The result in $\underline{\mathrm{a}}$ study by Meloret al. (2011) furthermore illustrated that environmental support factors such as teachers, parents and peer support showed favourable responses towards learner motivation.

Thus, this study hypothesized that service quality correlates with learner motivation in an English teaching context (H6).

\section{H7: Service quality correlates with learner attitude}

Some recent research has shown that different learner attitudes towards learning a language relates to the quality of teaching (e.g. Gan et al., 2004) or the efficiency of the 
learners in language classes. The results of the study by Meloret al. (2011) also illustrated that environmental support factors such as teachers, parents and peer support showed favourable responses towards learner attitude. Hence, in this study the hypothesis was (H7): service quality correlates with learner attitude.

\section{Methodology}

\section{Research method}

The methodology used in the study is the quantitative research methodology that builds on previous research in learner motivation, learner attitude, learner motivation, learner loyalty, and service quality.

\section{Research design}

A cross-sectional survey design was used in the study since the study aims to examine the relationships between the five factors - service quality, learner satisfaction, learner motivation, learner attitudes and learner loyalty. In particular, a multi-item questionnaire was developed to assess each latent factor and the links between them. To assess service quality, an adaption of the modified SERVQUAL was used. As the four factors (Assurance, Empathy, Responsiveness, Reliability) in the original SERVQUAL model are all related to teachers in the teaching context, in this study they were grouped as a factor 'Teachers'. Thus, this study assessed service quality that influences learner satisfaction through a modified SERVQUAL model with 4 dimensions: teachers, courses, tangible factors (facilities, study materials, study environment), and support services (registration process, information update).

\section{Questionnaire design}

The questionnaire's items were developed based on the literature review. The questionnaire then was reviewed by 12 people from different professions (English 
teacher, life scientist, physiologist, English learner, engineer, and survey professor) $\underline{\text { in }}$ order to gather suggestions for improvement from people in different walks of life.

\section{Questionnaire structure}

The survey instrument consists of 3 parts: Background information, English teaching and Open question. The $1^{\text {st }}$ part contains 7 questions about general information and language information (from the questions 1 to 7 ). The $2^{\text {nd }}$ part includes 49 questions (from the questions number 8 to number 56) related to the five factors: service quality, learner satisfaction, learner motivation, learner attitudes and learner loyalty. The 49 questions are the 49 dependent variables used to verify the conceptual model. The dependent variables were rated by a five-level Likert scale where 1 represents 'strongly disagree'; 2 represents 'disagree', 3 'neutral'; 4, 'agree'; 5, 'strongly agree'. Regarding the languages, the questionnaire was developed with two versions: English version and bilingual (English and Spanish) version.

\section{Research model}

The research model depicted in Figure 1 below represents the hypotheses that were tested in this study (as presented in the hypothesis development part). The model was used to simultaneously assess the five factors: learner motivation, learner attitude, service quality, and learner satisfaction and learner loyalty. 


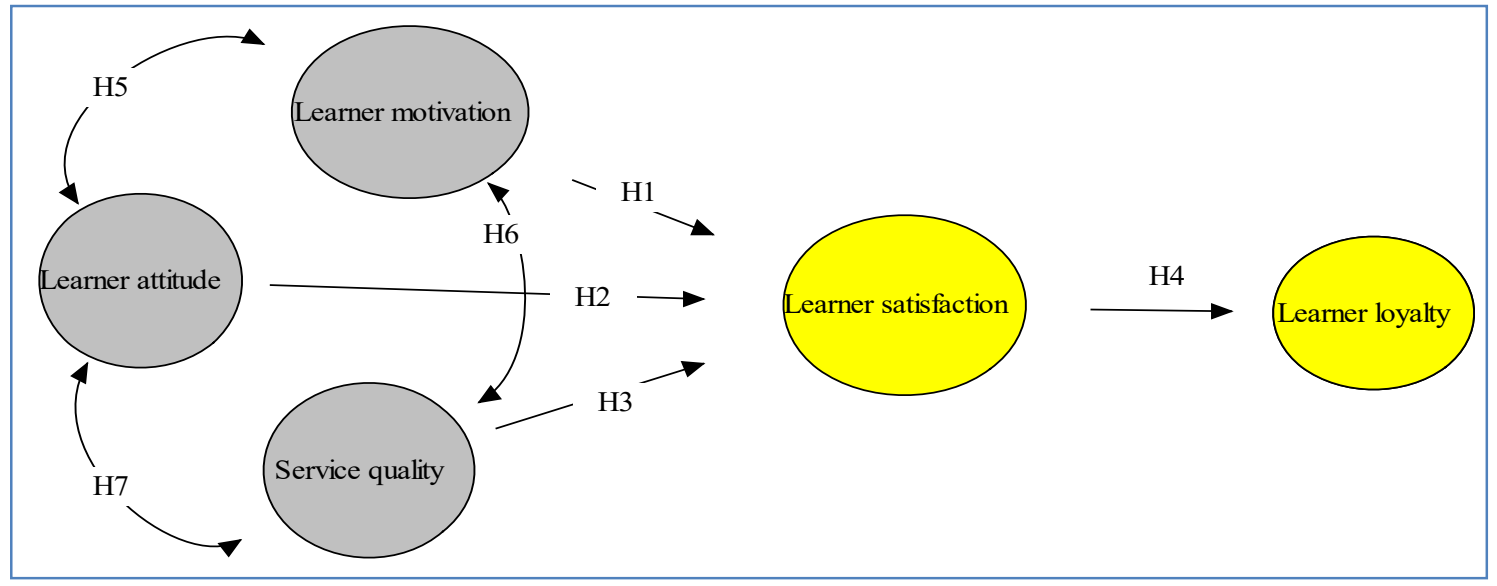

Figure 1.Conceptual model.

\section{Participants}

The survey was conducted in 5 English institutions in Gerona and Barcelona. The 334 learner participants were distributed across the five English levels: A2, B1, B2, C1 and

C2. There are 273 learners who were asked in the break time of their classes and 61 random learners who were asked when they were in the bar of their universities.

\section{Data collection}

The researcher went to 7 different English schools and talked with a particular English teacher in each school about the questionnaire. The researcher explained to the teacher the purpose of the study and the benefits that the school may get from the study. With the permission of the teachers who were interested in the study, the researcher went to each class and explained directly to the learners about the survey. The researcher especially emphasized the importance of being honest when answering the questionnaire, and how each individual's answer is very important. The researcher delivered the questionnaire to learners and stayed in the classes while learners were answering it. By doing this, the researcher could assist learners with their doubts and could motivate the learners to answer honestly without any pressure. 
The data was collected from $7^{\text {th }}$ May, 2014 to $23^{\text {rd }}$ May, 2014. This is a suitable timeframe since most English courses were about to be finished, so learners were be able to evaluate the whole course better.

\section{Data analysis and results}

\section{Data analysis procedure}

In the study, the computer program EQS version 6.1 was used to analyze data. EQS implements a general mathematical and statistical approach to the analysis of linear structural equation systems (Bentler, 2006).

Exploratory factor analysis (EFA) was conducted before confirmatory factor analysis (CFA). By using exploratory factor analysis, the dimensionality of a measurement instrument is explored by finding the smallest number of interpretable factors needed to explain the correlations among a set of variables. Confirmatory factor analysis (CFA) was used after EFA to study how well a hypothesized factor model fits a new sample from the same population, or a sample from a different population - characterized by allowing restrictions on the parameters of the model.

\section{Results}

\section{Participants Demography results}

In the study, there are a total of 5 English institutions which were officially investigated. Regarding location, there is one English institution in the city (Barcelona, Spain) and 4 others in a town (Gerona, Spain). The two locations are considered popular tourist destinations, and the official languages are Catalan and Spanish. Regarding the variety of institutions, there are 3 types of English schools involved in the study: public schools, private schools, and regular schools. It can be seen that the study has quite a 
good sample of English schools, which means the results of the study can be more generally applicable.

Table 2 below shows the demography information of 334 interviewed learners in terms of gender, nationality, mother tongue, and language learning experience.

Table 2.Demographic characteristics of the interviewed learners.

\begin{tabular}{|l|l|l|l|}
\hline \multicolumn{2}{|c|}{ Characteristic } & $\begin{array}{l}\text { Total } \\
\text { number }\end{array}$ & Percentage \\
\hline \multirow{4}{*}{ Gender } & Female & 191 & $57 \%$ \\
\cline { 2 - 4 } & Male & 143 & $43 \%$ \\
\hline \multirow{5}{*}{ Age (years old) } & 10 to 19 & 79 & $23.65 \%$ \\
\cline { 2 - 4 } & 20 to 29 & 140 & $41.92 \%$ \\
\cline { 2 - 4 } & 30 to 39 & 56 & $16.76 \%$ \\
\cline { 2 - 4 } & 40 to 49 & 33 & $9.88 \%$ \\
\cline { 2 - 4 } & 50 to 59 & 21 & $6.29 \%$ \\
\cline { 2 - 4 } & 60 to 69 & 5 & $1.50 \%$ \\
\hline \multirow{5}{*}{ Mationality } & Born in Spain & 294 & $88.02 \%$ \\
\cline { 2 - 4 } & Not born in Spain & 40 & $11.98 \%$ \\
\hline & Catalan & 159 & $47.60 \%$ \\
\cline { 2 - 4 } & Spanish & 101 & $30.24 \%$ \\
\cline { 2 - 4 } & Catalan and Spanish & 46 & $13.77 \%$ \\
\cline { 2 - 4 } & English & 0 & $0.00 \%$ \\
\cline { 2 - 4 } & Others & 28 & $8.38 \%$ \\
\hline
\end{tabular}

Regarding gender, the number of female learners overall is greater than that of the males, accounting for $57 \%$ compared to $43 \%$.

Regarding age, most participants are in the age range 20 to 29 which accounts for $41.92 \%$ of the total sample. Even though learners with different ages from 10 up to 69 study English as second language that indicates different generations are aware of the necessity of English, younger generations seem to be more aware of the necessity of learning English.

Regarding nationality, there are 40 interviewed learners (equals to $11.98 \%$ the total of interviewees) who were not born in Spain. It can be seen that English has become more 
and more international since people tend to learn English even when they stay in nonnative English speaking countries. Moreover, the figure also indicates that the two cities investigated are popular choices for foreigners to live. $8.38 \%$ of interviewees are either not English native speakers or Spanish/Catalan native speakers.

Regarding the English levels of interviewees, overall, the majority of learners have an intermediate level of the 4 skills. The figures are $59.58 \%, 57.78 \%, 64.67 \%$, and $62.57 \%$ for listening, speaking, reading and writing skill respectively. Among the 4 skills, the speaking skill is the worst skill, since the number of interviewees with advanced, intermediate and elementary level of speaking is the lowest and the number of beginners for this skill is the highest. This can be explained by the fact that even though the two cities are international, people do not have many chances to practice English to foreigners since foreigners tend to learn and speak local languages.

\section{Factor analysis results}

Exploratory factor analysis (EFA) was conducted to find the smallest number of interpretable factors needed to explain the correlations among a set of variables. After conducting EFA for 9 items (equivalent to the 9 questions in the questionnaire), there are two factors extracted since their Eigen values are 2.512 and 2.089 that are greater than 1. Items which have factor loadings greater than 0.5 are then selected for the two extracted factors (Bentler, 2006). The two extracted factors can be seen as intrinsic motivation and extrinsic motivation. Similarity, one factor extracted from 5 items of attitude; four factors (tangibles, courses, support services and teachers) extracted from 20 items of service quality; one factor extracted from 10 items of satisfaction and one factor extracted from 5 items of loyalty.

Confirmatory factor analysis (CFA) was used after EFA to correlate all factors obtained using the structural model with 7 factors extracted (F1- extrinsic motivation, F2 - 
intrinsic motivation, F3 - learner attitude, F4 - Tangibles, F5 - Courses, F6 - Support services, and F7 - Teachers).

The measurement model was estimated by using the robust maximum likelihood method of EQS 6.1. The model obtained from CFA is demonstrated in Figure 2 above with all the coefficient values of all latent factors.

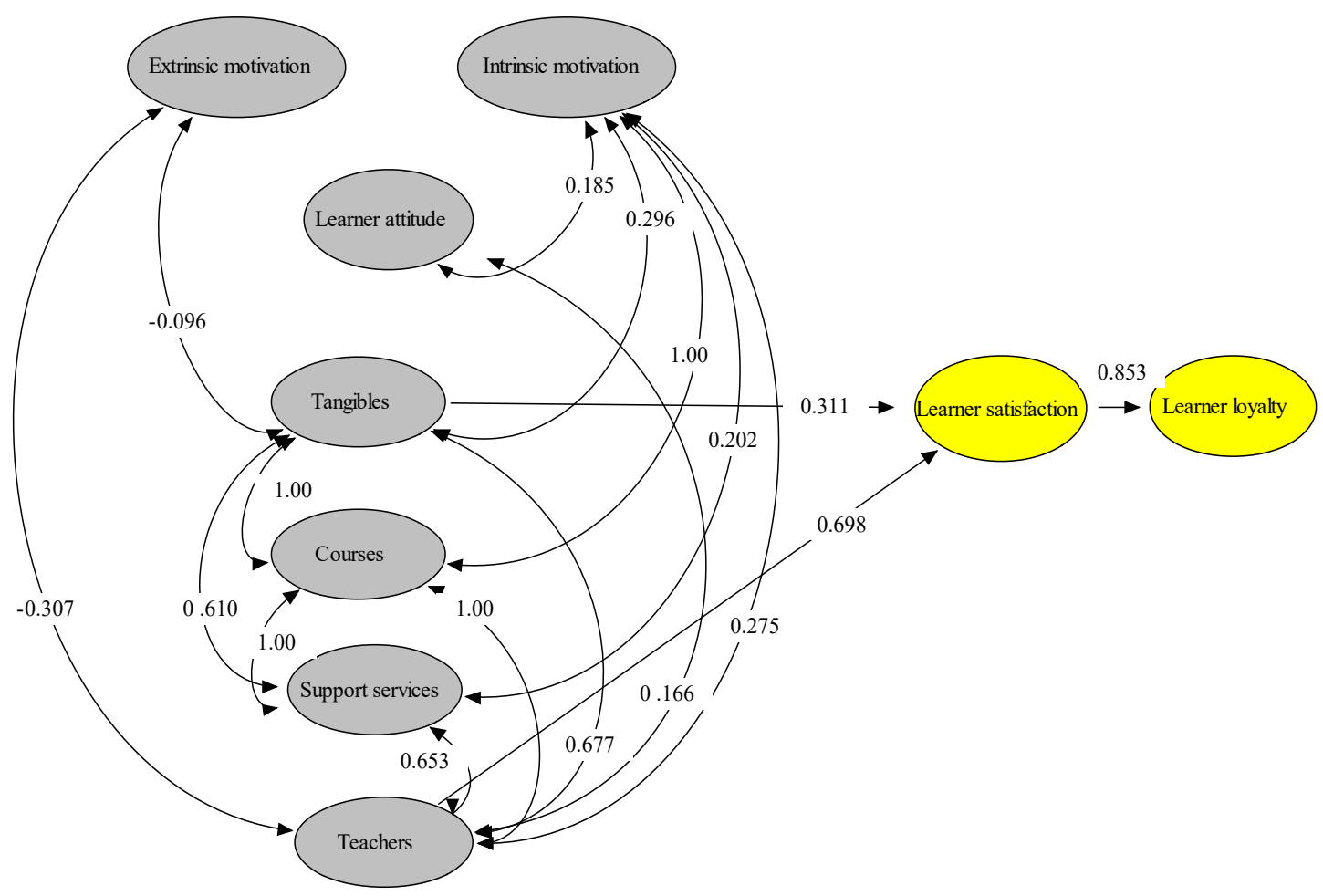

Figure 2. Model obtained after CFA.

The data analysis showed that model has a good fit because:

- The Chi-square value is 1370.331 based on 673 Degrees of freedom so Chisquare divided by Degrees of freedom is approximately 2.036 that is much less than 5.

- Comparative Fit Index (CFI) is 0.898 that is quite high.

- Root Mean-Square Error of Approximation (RMSEA) is 0.056 which is smaller than 0.08 that also means the model is good fit (MacCallum et al., 1996). 
Table 3 below gives information about the covariance among the seven factors.

Table 3. Covariance among independent variables.

(Significant at the 5\% level are marked with @)

\begin{tabular}{|c|c|}
\hline $\begin{array}{c}\text { Independent } \\
\text { variables }\end{array}$ & Covariance \\
\hline F2-F1 & -1.276 \\
\hline F3-F1 & -1.456 \\
\hline F4-F1 & $\mathbf{- 2 . 2 2 7}$ \\
\hline F5-F1 & -0.968 \\
\hline F6-F1 & 0.833 \\
\hline F7-F1 & $\mathbf{- 4 . 0 0 3}$ \\
\hline F3-F2 & $\mathbf{2 . 2 8 4}$ \\
\hline F4-F2 & $\mathbf{3 . 6 9 6}$ \\
\hline F5-F2 & $\mathbf{2 . 3 9}$ \\
\hline F6-F2 & $\mathbf{2 . 5 6 2}$ \\
\hline F7-F2 & $\mathbf{3 . 8 6 7}$ \\
\hline F4-F3 & 1.012 \\
\hline F5-F3 & 1.287 \\
\hline F6-F3 & 0.946 \\
\hline F7-F3 & $\mathbf{2 . 2 9 9}$ \\
\hline F5-F4 & $\mathbf{5 . 8 0 1}$ \\
\hline F6-F4 & $\mathbf{5 . 8 0 2}$ \\
\hline F7-F4 & $\mathbf{7 . 5 0 5}$ \\
\hline F6-F5 & $\mathbf{6 . 4 1 4}$ \\
\hline F7-F5 & $\mathbf{7 . 5 3 2}$ \\
\hline F7-F6 & $\mathbf{6 . 6 4 2}$ \\
\hline & \\
\hline & \\
\hline & \\
\hline & \\
\hline & \\
\hline & \\
\hline & \\
\hline & \\
\hline
\end{tabular}

According to Bentler (2006), if the @-sign is smaller than 2 or 1.96 then the relationship between two factors will be not significant. In contrast, if the figure is greater than 1.96 or 2 then the link is significant and the relationship should be interpreted. Therefore, Hypothesis $\mathrm{H} 1$ and $\mathrm{H} 2$ were not supported while Hypothesis H3, H4, H5, H6 and H7 were supported.

\section{Findings and Discussions}

\section{Assessing learner satisfaction}

Learner satisfaction and learner motivation 
According to the results of the analysis, the motivation of the English learners in this study does not have a strong direct effect on their satisfaction. However, this study showed that learner motivation and learner satisfaction have an indirect relationship via service quality. It means that no matter what the reasons are for learning English, learners can still feel satisfied as long as the quality of teaching is good.

\section{Learner satisfaction and learner attitude}

Data analysis shows that learner attitude and learner satisfaction are insignificantly interrelated. So in an English teaching context, learner attitude towards the importance of English learning does not have much influence on their satisfaction. However, they have an indirect link via service quality. This means that it is not really important how learners themselves feel about English learning, they can still feel satisfied as long as the quality of teaching is good.

\section{Learner satisfaction and service quality}

According to the data analysis, two dimensions of service quality, including teachers and tangibles, are significantly related to learner satisfaction while the two other dimensions (support services and courses) have an insignificant direct relationship with learner satisfaction. This finding of the study supports the results of previous studies in terms of indicating teachers and tangibles (facilities, materials and learning environment) have a significant and positive impact on learner satisfaction (Mai, 2005; Babar and Kashif, 2010; Ali, 2013).

However, the two low impacting factors have a strong positive relationship with the two high impacting factors. It means that to improve the quality of English teaching to enrich the high level of learner satisfaction, it is necessary to simultaneously improve all the four factors, especially the two factors - teachers and tangibles.

\section{Assessing the impact of satisfaction on loyalty}


The analysis implies that learners will become much more loyal when they receive the better services. It supports the results that have been shown in recent research that learner satisfaction has a great influence on learner loyalty (Zhaohua et al., 2010; Leyla and Ali, 2012). From this; the institutions need to focus on increasing learner satisfaction to get more loyal customers who re-purchase the service or recommend to their relatives.

\section{Assessing the three constructs that are considered as antecedents of satisfaction:}

\section{learner motivation, learner attitude, and service quality}

\section{Learner motivation and learner attitude}

According to the data analysis, extrinsic motivation has an insignificant negative relationship with learner attitude while intrinsic motivation has a direct positive relationship with learner attitude. It means that when learners themselves are motivated to learn English, they may have a good attitude towards English. On the other hand, if they have to study English because of external factors like job requirements, they may have a bad attitude towards English.

\section{Learner motivation and service quality}

According to the data analysis, all dimensions of service quality have positive impacts on intrinsically motivated learners, while only teachers and tangibles link with extrinsically motivated learners. The two dimensions - tangibles and teachers - have the biggest impacts on intrinsically motivated learners whilst the two dimensions have a negative relationship with extrinsic motivation.

This finding makes a contribution towards clarifying the relationship between the service quality and the two types of motivation - intrinsic and extrinsic - since previous studies only approached the relationship between service quality and motivation in 
general (e.g. Nada, 2010 stated that teachers and course positively affect learner motivation toward learning English).

\section{Learner attitude and service quality}

Attitude has a strong positive direct link with service quality through only one factor (teachers) among the four factors used to assess service quality. So teachers need to have solutions to encourage students to help them get a good attitude towards English learning.

\section{Links between the two types of motivation}

Extrinsic motivation and intrinsic motivation have an insignificant negative relationship. An explanation for this could be that learners will be less intrinsically motivated if they have extrinsic motivation.

\section{Link between the four factors of service quality}

Service quality in the English teaching field can be measured by a modified SERVQUAL model including 4 dimensions: Tangibles (studying materials, studying environment, and equipment), Courses, Support services, and Teachers. Among the 4 dimensions, the most important factor influencing service quality is "Teachers" and the second most important factor influencing service quality is 'Tangibles'. The four factors have strong relationships with each other, and teachers have the most significant relationship with all other three factors. This means that to improve the service quality, English institutions need to focus on improving all the factors: tangibles, courses, support services and especially teachers. Schools need to be aware of the important role of teachers to create good teaching conditions for them. The teachers then need to have their own solutions to motivate students and use all the given conditions to provide the best teaching services to learners. 


\section{Conclusions}

It is important for both institutions and individual teachers to work on improving the quality of teaching to help learners become more motivated and have a better attitude toward learning English, as well as to enrich overall learner satisfaction. By doing this, learners will become more loyal, demonstrating the effectiveness of the institutions. Learners themselves need to work on learning English and use all the positive conditions provided by the schools and teachers to improve the English learning experience. This study lays a foundation for how the five factors (learner motivation, learner attitude, learner satisfaction, learner loyalty and service quality) support and relate to each other in the English teaching field. The method used in the study can be implemented in the same field in other areas or other countries. Furthermore, it can be facilitated for simultaneously assessing customer satisfaction with the four other factors in other fields. A replication study or other approaches to customer satisfaction should be conducted in the future to support the findings of the study.

\section{Acknowledgement}

This research was done with the support of Prof. Andrea Bikfalvi, 12 English teachers (Vivien Greatorex, Tom Burns, Linda Moody and Imogen Prince from Modern Language Services University of Gerona; Ana Isabel Pons, Josep Maria Cabre and Miriam Romanacu from EOI Barcelona Drassanes; Elisabet Codern from EOI Gerona; Marc Toone from Up! Idiomes; Sophia Roisin and DolorsPla from Maristes Gerona) and 334 English learners in Spain.

\section{Notes on contributors}

Jennifer Vu Huong is a Masters student in Business Innovation and Technology Management at the University of Gerona. 
Marti Casadesus Fa is a Professor in the Department of Business Management and

Product Development at the University of Gerona. His research is focused on quality

management.

Frederic MarimonViadiu is a Professor in the Department of Economy and Business

Organization at the Universitat Internacional de Cetalunya. His research is focused on

quality management.

\section{References:}

Agita Smitina, 2010, The link between vocational identity, study choice motivation and Satisfaction with studies, Social and Behavioral Sciences 5 (2010)1140-1145.

Arbaugh, J. B. (2000). Virtual classroom characteristics and student satisfaction with online MBA courses. Journal of Management Education, 24(1), 32-54.doi:

10.1177/105256290002400104.

BabarZaheerButta, KashifurRehman,Astudyexaminingthelearnerssatisfactionin highereducation,SocialandBehavioralSciences2(2010)5446-5450.

Bentler, P.M., 2006, EQS Structural Equations Program Manual, Encino, CA:

Multivariate Software, Inc.

Deci\&Ryan(1980), Extrinsic Rewards and Intrinsic Motivation in Education, Review Of Educational Research Spring2001, Vol.71, No.1,pp, 1-27.

Elliott,K.M., \&Shin,D.(2002). Learner satisfaction: An alternative approach to Assessing this important concept.Journal of Higher Education, 24,197-209.

Gan, Z., Humpreys, G., \&Hamp-Lyons, L. (2004). Understanding successful and unsuccessful EFL learners in Chinese universities. The Modern Language Journal, 88, 229-244.

Gardner,R.C., \&Lambert, W.E. (1972).Attitudes and motivation in second language learning.Rowley,MA:Newbury House.

Gardner,R.(1985). Socialp sychology and second language learning: therole of attitude and motivation.London:EdwardArnold.

Gitman,LawrenceJ.; CarlD.McDaniel(2005).The Future of Business: The Essentials.Mason, Ohio:South-Western.ISBN0-324-32028-0.

Helgesen,O.,\&Nesset, E. (2007). What account for learners"loyalty? Some field Study evidence.International Journalof Educational Management,21(2),126-143.

Hsiu-Feng Shih, Shu-Hui Eileen Chen, Shu-Chu Chen, Shyh-Chyi Wey, 2013, The Relationship among Tertiary Level EFL Learners' Personality, Online Learning Motivation and Online Learning Satisfaction, Social and Behavioral Sciences 103 ( 2013 ) $1152-1160$.

LeoZ.Hsiu-Feng Shih, Shu-Hui Eileen Chen, Shu-Chu Chen, Shyh-Chyi Wey, 2013,The Relationship among Tertiary Level EFL Learners' Personality, Online Learning Motivation and Online Learning Satisfaction, Social and Behavioral Sciences 103 (2013) $1152-1160$.

Leo Z. Archambault, Mount Ida College, Measure service performance, learner satisfaction and its impact on learner retention in private, post-secondary institutions, originally published in the Proceedings of the EDU-COM 2008 
International Conference.Sustainability in Higher Education, 19-21 November 2008.

LeylaTemizer andAliTurkyilmaz, 2012, Implementation of learner satisfaction index Model in higher education institutions,Socialand Behavioral Sciences46(2012)38023806.

Lim,D.H.(2004).Cross cultural differences in online learning motivation.

Educational Media International, 41(2), 163-173.

MacCallum, R.C., Browne, M.W., and Sugawara, H., M. (1996), "Power Analysis and Determination of Sample Size for Covariance Structure Modeling," Psychological Methods, 1 (2), 130-49.

Mai,L.-W.(2005).A comparative study between UK and US:The learner satisfaction In higher education and its influential factors.Journal of Marketing Management,21, 859-878.

MelorMdYunus,NurRashidahKhairunnisaRanjeetaBt. Abdullah, 2011, Motivation and attitudes for learning English among year six learners in primary rurals chool, Social and Behavioral Sciences 15 (2011)2631-2636.

Nadiri,H.,Kandampully,J.,\&Hussain,K.(2009).Learner"s perceptions of service qualityinhighereducation.TotalQualityManagement,20(5),523-535.

NadaAlRifaia,2010, Attitude, motivation, and difficulties involved in learning the Englishlanguageandfactorsthataffectmotivationinlearningit,Socialand BehavioralSciences2(2010)5216-5227).

Navarro, M.M., Iglesias, M.P., \& Rivera Torres, P. (2005). A new management element for universities: Satisfaction with the offered courses. International Journal of Educational Management, 19(6), 505-526.

Nasser Oroujlou,\& MajidVahedi,2011,Motivation,attitude,andlanguagelearning, Social and Behavioral Sciences29 (2011)994-1000.

Patterson, Paul G., Lester W.Johnson and Richard A.Spreng (1997), "Modeling the Determinants of Customer Satisfaction for Business-to-Business Professional Services, "Journal of Academy of the Marketing Science, 25 (Winter), 4-17.

Parasuraman, A., Zeithaml,V.A.,\& Berry,L.L.(1985).A conceptual model of service quality and its implications for future research.Journal of Marketing, 49, 41 50.

SprengR.A.\&MackoyR.,(1996). An Empirical Examination of a Model of Perceived Service Quality and Satisfaction.Journal of Retailing,72(2).

Stodnick,M.,\&Rogers,P. (2008).UsingSERVQUAL to measure the quality of the classroom experience. Decision Sciences Journal of Innovative Education,6(1), 115-133.

Youssef,A.M.S. (2012). Role of Motivation and Attitude In Introduction And Learning Of English As A Foreign Language In Libyan High Schools. International Journal of Linguistic, 4(2), 366-375.

ZhaohuaDeng,Yaobin Lu,KwokKeeWei,JinlongZhang,2010,International Journal of Information Management 30(2010)289-300. 